\title{
Testing the Boundaries: Reflections on Transnationalism in Australian history
}

Anna Clark, Anne Rees and Alecia Simmonds

Transnational history in Australia is in an ebullient mood. Ten years after Marilyn Lake and Ann Curthoys' path-breaking work, Connected Worlds, there has been an entire generation of scholars raised on mantras of mobility, imperial circuitry and the need to think beyond national borders. "Entangled histories" are the new orthodoxy, and circulation metaphors pepper the scholarly lexicon. ${ }^{2}$ Within a remarkably short time, transnational history has moved from the margins to the mainstream. Only recently a radical critique of national historiographies, it is today among the most influential forms of history making. ${ }^{3}$ In the wake of these developments, our conception of the Australian past — and the work of historical research and writinghas been transformed. No longer a quarantined field of study, Australian history now appears on the outer rim of Pacific and Indian Ocean studies; as a nodal point in British imperial studies and connected, or cast in comparative light, with other settler colonial nations. The transnational has become not only a type of counter-narrative to the nation; it has also helped complicate our understandings of national history. ${ }^{4}$

After first emerging in American historiography in the early 1990s, the "transnational turn" has since been embraced by scholars throughout the English-speaking world. European historians, also, have taken up histoire croisée and Transfergeschichte. Latin Americanists map the hybrid space of borderlands. The vogue for the transnational is very much a transnational phenomenon. But amid this international scholarship, especially in the United States, the mood is turning. The grand hopes that accompanied the early years of the transnational turn have given way to more 
measured reflection, as commentators assess the insights and shortcomings of the first generation of entangled histories. In Australia, by contrast, criticism of our new panoramic lenses has been muted or confined to suggestions for new directions: more non-Anglo-American sources, more linguistic diversity, less hagiography, more ocean-centred histories and more efforts to think about connections outside of European empires or nations. ${ }^{5}$ Yet the methodological novelty of transnational history persists unquestioned. Amidst the rush to think and research outside the nation, the social conditions of transnational scholarship and its ontological privileging of particular historical processes have remained unchallenged in Australia.

This collection offers a moment to pause. We ask those who have quietly continued their nation-focused studies to speak up. We ask advocates of transnational history to reflect honestly on the personal and professional benefits and costs of a peripatetic research methodology. And we hope to open a critical and reflexive space to look back upon the past two decades and evaluate the promises, pitfalls and politics of transnational history. The first question we might ask is: what's new? How has transnational history changed Australian national history? Has it opened up new sources and new analytical lenses in the manner of cultural or social history, or has it confined itself to a reinterpretation of old archives; a widening of old spatial boundaries? Is it, in the words of Matthew Pratt Guterl, "like a transparency laid over a familiar map?"

Transnational history, as outlined by Curthoys and Lake, had modest aims: to allow for a study of "the ways in which past lives and events have been shaped by processes and relationships that have transcended the borders of nation states." To date, the 
innovations have been mostly spatial: histories of migration and travel have illuminated the movement of convicts, missionaries, traders, immigrants, institutions and ideas across national borders. Digitisation has made our history bigger, allowing us to conduct large-scale global surveys based on quantifiable data, but this has been achieved by rendering old archives more accessible rather than opening up new, fugitive archives. And digitisation also comes with pitfalls of its own, not least of which is the loss of the "place-specific learning" once built into the research process. In the absence of what Lara Putnam terms "real-world friction," even experienced researchers can too easily make "rookie mistakes." 8

Meanwhile, national time lies undisturbed. The geographic ambition of the new transnational histories has not yet occasioned an accompanying temporal shift in historiography (beyond environmental and archaeological approaches). ${ }^{9}$ Our basic modes of periodization - from pre-contact Indigenous history to colonial history, Federation-era, interwar and post-war - for the most part remain bound to and determined by the nation. The space of Australian history has exploded; its time, as in other national contexts, is little changed. Where have we linked our new understandings of Australia's place in the world to global temporalities? What new “temporal plot points" might our transnational scholarship generate? ${ }^{10}$

We may also query the social conditions of our own historical productions; to historicise our practice in the present. To what extent is our fascination with a borderless past inhabited by mobile subjects a product of our own privileged cosmopolitanism? Observers of the field note a phalanx of first-world academics, flying on the wings of generous research grants, swooping and feasting on global 
archives. ${ }^{11}$ More disconcertingly, to what extent is this creating a "professional standard" that could not be met by anyone without tenure or institutional support? Digitisation goes some way to defraying travel costs, but only if your sources come from a country wealthy enough to digitise their archives. For all its subversive rhetoric, the practice of transnational history typically rests on economic, racial and institutional privilege that leaves non-Western histories and historians behind. The scope of our scholarship has been enlarged to encompass more diverse peoples and places, but in a manner that arguably reinscribes the dominance of metropolitan voices. Far from "provincializing" the West, the time and cost of transnational scholarship risks making this an approach that further concentrates historical production in the hands of a privileged elite. ${ }^{12}$

We may also ask to what extent our conceptual frames and vocabularies are indebted to present-day economies. Are we not disturbed to find that the very metaphors that we draw upon to frame transnational histories are the same we find in neoliberal justifications for globalization: free flows and circuits of people and goods across national borders unperturbed by the state? Historians of capitalism remind us that our "connectivity talk" mirrors - even naturalizes - the borderless world envisaged by Wall Street and Silicon Valley, and easily elides the violence and inequality of connection. ${ }^{13}$ As Paul A. Kramer cautions, our "exuberant cosmopolitan fantasies of a mobile, interconnected world" can, at their worst, "provide present-day neoliberal globalism with a useable past." ${ }^{14}$ No longer handmaidens to the nation-state, are we now courtiers to late-capitalism? 
In the Australian context, we can further discern a stark re-inscription of anxious colonial relationships to the metropole. We unearth those areas of our history that will most please a global (read American or British) audience and forsake our own local audiences. Of course, this is encouraged by university administrations that too often base their rankings on fantasies of international prestige and connection at the expense of local impact. Although publishers still favour national stories, we strive to the grace the pages of international journals and present at international conferences, and shape our research accordingly. ${ }^{15}$ This quest to be heard in London or New York is all too familiar, strikingly reminiscent of nineteenth and twentieth century antipodean efforts to win validation from West End audiences, Fleet Street publishers or Oxford dons. In our twentieth-first century attempts to "stand up in the great world"-a phrased coined by poet Mary Gilmore in 1928 - we can see the latest incarnation of a time-honoured Australian tradition. ${ }^{16}$ But are we now confident global citizens, raising our voices in an international conversation, or are we still playing the part of adolescent nation, ever seeking the approval of our betters abroad?

And irrespective of the nature of this international orientation, it turns us away from domestic publics. When we project our voices outward, we create a local vacuum that risks being filled by the same chauvinist narratives that transnational history was created to displace. Speaking of the British context, Alison Twells chastises her globally inclined peers for neglecting national audiences and thereby allowing masculinist national histories to persist in the public sphere. "[W]e have lost our way," Twells laments, and forsaken the "radical and democratic aims" that underpinned the original critique of national historiographies. ${ }^{17}$ Can the same be said of Australia, where bestseller lists contain few works of scholarly history, and even 
fewer that contain transnational content? In an age of fast revivifying national chauvinism, these are far from idle concerns.

Beyond the politics of transnational scholarly practice, the historiographical preference for supranational subjects contains a politics of its own. What gets lost when we privilege historical processes that are self-evidently global? With its focus on exploration, trade, migrants and travellers, transnational history contains little space for the sedentary majority. In the rush to rediscover the flow of people and things, the static and the vernacular are deprioritised. When connection and mobility are the catchwords $d u$ jour, their opposites are too easily cast aside. Again, these hierarchies militate against a more inclusive vision of the past. Although recent Australian scholarship has tracked the movement of Indigenous peoples, Indian hawkers, and professional women, the search for history's mobile subjects will most reliably favour the white men whose gender and race conferred the freedom to leave home and cross borders at will. ${ }^{18}$ Their predominance in the transnational archive is especially stark in the nineteenth century, when the large majority of women were condemned to stasis by the labour of care while poverty often condemned men to mobility. Within a historiographical climate oriented toward towards global networks, the proverbial "woman from Queensland" who "spent her life working in pubs and shops" will, as Christina Twomey notes in her chapter, yet again struggle to win a place in the spotlight.

Other victims of our transnational preoccupations may include individual agency and local context. When we zoom out to a regional, oceanic or global scale, can we hold true to the specificities of people and place? To what extent does a bigger canvas 
necessitate broader strokes? To date, biography has been the favoured solution to this dilemma, the easiest and seemingly most effective means to preserve the micro-scale of individual lives and their immediate contexts within the magnified field of transnational scholarship. The study of "transnational lives" is a booming industry, both within Australia and overseas, with local publications such as the 2010 edited collection Transnational Lives: Biographies of Global Modernity cited as international exemplars of the field. ${ }^{19}$ At its best, this practice can, as Linda Colley writes, chart "a world in a life and a life in a world," and "tack between the individual and world histories 'in such a way as to bring them into simultaneous view'."20 Yet the problem with transnational biography is that it highlights anomalous lives: the global elites or rare miscellaneous wanderers who were more mobile than most and, crucially, left records of their travels. For every non-elite global citizen such as Colley's Elizabeth Marsh-or, to cite a local example, Fiona Paisley's "lone protestor," A. M. Fernando-there are thousands more who never ventured beyond national borders. ${ }^{21}$ How might these "ordinary" masses be incorporated into transnational history?

Ann McGrath's award-winning new study of interracial marriage presents one route forward, with its insistence that transnational crossings also occurred between "colonizer nations" and "First Nations" co-located within the bounds of a single nation-state. By fixing her gaze on what she terms the "colonizing transnational," McGrath is able to write transnational biographies of Indigenous women whose mobility was more mental than physical. ${ }^{22}$ Also promising are projects that delineate the transnational constitution of domesticated lives and communities, such as Jon Piccini's research into the "worlding" of 1960s Australian radicals. ${ }^{23}$ Such scholarship 
points to the possibilities of transnational approaches: the urgent movement of ideas such as democracy, radical Islam, indigenous and civil rights, peace, environmentalism; the need to see historical subjectivity without, as well as within, national borders; and the potential to recast seemingly national "moments" in global contexts.

Like many Australian historians we have found ourselves increasingly pondering the limits and boundaries of national history in this age of transnationalism. But we realized we could not represent that diversity of historiographical accounts and reflections on our own. The inspiration for this collection comes from an Academy of Social Sciences in Australia (ASSA) Workshop, held in 2015, which explored the place of transnational histories in Australian historiography and historical practice. Given the powerful challenge in recent years to the "national narrative" by transnational and international historical perspectives, the workshop presented an opportunity to examine the discipline of Australian history in light of these critical new approaches. Transnational histories have sought to break down simplistic distinctions between "global", "world" and "national" histories by showing that global forces (networks, ideas, institutions, processes) do not simply "transcend" nation-states, they also create them. Transnational history is preoccupied with highlighting the instability and historical contingency of the modern political terms we often take for granted, such as "nation-state" and "national community."

Key moments in Australian history, such as colonisation, Eureka, federation, Australians at war, and the recognition of Indigenous rights, have been increasingly re-examined with a transnational lens, raising important questions about the unique 
context of Australia's national narrative. Meanwhile, the pervasiveness of the "Australian story" reveals the enduring resonance of the nation in public historical discourse and scholarship. The so-called "history wars," including contests over the national history curriculum, museum exhibits and national commemorations, continue to generate heated discussion around the country. Popular history books drawing on explicitly national stories such as Anzac, Kokoda and Eureka are consumed avidly by an Australian readership, as are heritage tours, Australian historical fiction and television. These popular expressions of Australia's past demonstrate that people around the country - not just historians, public commentators and politicians - care deeply about, and connect to, historical narratives that are explicitly national.

In response, we hope this collection offers an examination of the tension between these national and transnational perspectives today: we recognise the critical need to internationalise the often parochial nation-based narratives that characterise the history wars, for example, or the glorification of the Anzac Legend; and we are similarly drawn to study the mobility of lives and ideas as ways to break out the apparent teleology of "the national story." But we also sense the limits of transnational histories in Australia, where histories are primarily produced for a national audience, where a strong national discourse resonates powerfully in public debate, and where those very mobilities can overlook the vernacular and intimate in everyday Australian life. The "nation" remains the central framework of historical discussion for good reason.

At a time when Australian history seems to be moving in two distinct directions, this collection brings these diverging national and transnational approaches together for a 
timely consideration. Leading scholars and commentators from around the country reflect on their historical practice, and ask several critical research questions: What are the implications of transnational and international approaches on Australian history? What possibilities do they bring to the discipline? And, significantly, what are their limitations?

As a way into some of these questions, the collection is structured in three sections that move from the global to the local and personal. The first encompasses comparative and international research, drawing on the experiences of eminent researchers working across nations and communities. What is transnational history? How do new transnational readings of the past challenge conventional national narratives and approaches? Ian Tyrrell, Miranda Johnson, Anne Rees and Patricia Grimshaw turn the lens to their own work and tease out some of the implications of reading Australian history using a transnational approach.

These chapters centre on the themes of environmental history, Indigenous histories and women's history, which have been central to the development and distinctiveness of transnational histories. Each demonstrates the capacity of the transnational turn to develop new material, interpretations and approaches to Australian history. For example, both Rees and Johnson explore the concept of mobility - actual, as well as intellectual, political, and ideological - to present new understandings of Australian women's and Indigenous history. Yet these authors also negotiate that constant creative tension between the potential of transnational approaches to recast national narratives, and the need for those same narratives to contextualise and ground the transnational. 
Patricia Grimshaw documents the transnational influences in feminist historical scholarship in Australia, and argues that feminist historians' "deployment of transnational frameworks empowered Australian women's historians to intervene profoundly in the national historiography: their work was transnational in inspiration, national in its focus, substance and impact." While it "would be an exaggeration perhaps to claim that the first practitioners and those who followed displaced central understandings Australia's past," she continues, "we can have no doubt that they offered a robust counter narrative." That potential for transnational methods to provide the groundwork for counter narratives to national historiographies echoes the work of Tracey Banivanua Mar and Penny Edmonds, who recognise the importance of understanding the local specificities and transnational structures of settlercolonialism, for example, and whose work has substantially influenced the conceptualisation of this collection. ${ }^{24}$

That does not mean the national disappears in transnational analysis; far from it. As Ian Tyrrell has famously asked, "How can the nation-state be incorporated into this project" of transnational history, since much "history is still written in terms that accept the primacy of the national focus"? ${ }^{25}$ Using environmental histories of the Cooks River in Sydney and Los Angeles River in the US, Tyrrell expands his thesis in this collection, and shows that while "place can be transnationally conceived, constructed, and transmitted," these "transnational elements of place-making are shaped and limited by the particularities of the physical environment and the succession of cultural landscapes modifications undertaken." In other words, place is imagined and inscribed locally as well as utilised as a transnational concept. 
Section two includes commentary on the enduring role of the nation in national historiography. How do we write national histories that are attentive to global influences? What does the nation look like after the transnational turn? If Bongiorno, Macintyre, Brett and Twomey are any indication then we must conclude that Australian histories are now irrevocably transnational. To paraphrase Bongiorno, the nation is revealed to be contingent and artificial; embedded in and shaped by cosmopolitan networks. All four scholars are committed to writing specifically Australian history, which requires they adopt scholarly lenses that allow them to peer beyond national borders. For Bongiorno, reflecting on his recent book, The Eighties, Labor's shift to economic rationalism or a more market-oriented policy can only be understood as a product of global forces meeting a specific Australian context. Twomey traces the provenance of Australian ideas about the "protection" of Indigenous people to the management of slaves and other non-citizen, non-criminal groups by European empires beginning in the sixteenth century. Macintyre finds that Australian post-war reconstruction consisted of an eclectic range of policies that were pursued through diplomacy and international organisations but enacted and applied by national governments. And the figure of Alfred Deakin makes little sense to his most recent biographer, Judith Brett without attending to the international, particularly American, influences which shaped him and how he saw his life.

Yet acknowledging transnational influences does not mean writing transnational history. One of the key differences that Bongiorno and Brett identify is the question of audience, as Brett asks: "who is our imagined readership and where do we publish?" Keen to overcome the problem of historians' lack of public engagement and their 
usurpation by journalists, Brett exhorts at least "some of us [to] write primarily for our fellow citizens" rather than international journals which means crafting narratives that are more likely to challenge or appeal to readers with local knowledge. While writing nation-focused history may win historians a wider audience, it will also quite possibly lose younger historians a job or impede career progression, as Twomey, Bongiorno and Brett all lament. Twomey argues that transnational history became a particularly attractive option as academics felt increasing institutional pressure by universities keen to improve their rankings to internationalise scholarship, which meant publishing in international journals and publishing with international presses at the expense of local readers. Bongiorno suggests that the peculiarly privileged position of academics as mobile, cosmopolitan elites, may also explain the ease with which we all put on our transnational lenses. While all authors recognize that the new sources and new questions opened up by transnational history are exciting, Twomey warns against transnationalism's “overdeterminism." What marginal figures, what complex inner-worlds are we ignoring when we stop excavating the forgotten subjects of social and cultural history? Who is obscured by the panoptical overview favoured by global history?

The last section includes evaluations on the influence of transnational approaches on intimate and vernacular histories. Is the boom in family history a transnational phenomenon? Or is it intimately tied to particular national narratives? In this final part of the book, the potential for researchers to understand the possibilities and limits of transnational histories is particularly prescient: how do we understand the nation in this transnational moment? How can we focus on broad transnational forces without 
losing sight of the local and the particular? And how does such research offer insight into the future of the history discipline in Australia?

The desire to write histories that place past lives - their inner-worlds, private desires and nuances - within a global context is of particular concern to scholars of intimacy. As Boucher/Reynolds and Simmonds attest, intimacies are shaped by public discourses that often exceed the national context and, as Clark/Evans illuminates, local interest in writing about intimacy is a global phenomenon. The chapters in this final section bring family history and the history of the emotions into conversation with transnational and national history in divergent ways. In their project on the citizenship claims of gay men since the 1970s, Boucher and Reynolds have exposed how seemingly national concerns, such as state-based demands for legislative reform, were inflected with psychological discourses of authentic selfhood that traversed the Anglophone world. In so arguing, they expose how the transnational can be used to dispute claims to national distinctiveness and to nationalist histories that claim ownership of gay narratives. Evans and Clark also move between the transnational dimensions of family history - how local studies of family trees uncover international roots - and the transnational moment of the practice of doing family history: the global popularity of a distinctively local and seemingly national practice. Simmonds inverts the focus by looking at intimacy less as something governed by the nationstate than constituted within legal practices. Focusing on the Pacific in the eighteenth Century she finds that the term "taio" or its European cognate "friendship" was a space of legal encounter between cultures and countries. As such, she questions the implicit Eurocentrism evident in much transnational literature and raises questions about how to incorporate non-European epistemologies. 
In the following chapters, each of the authors writes about their own practice, and their own negotiation of the national and transnational, in the context of their research. Taken together, they explore disciplinary questions about the tensions between national and transnational historical approaches. And in doing so they ask, implicitly: is the nation ever really displaced by transnational histories? Is it possible to write national histories without drawing on transnational approaches? What historical questions does a transnational approach illuminate or obscure? In answering those questions yet more are generated: how innovative is transnational history? Does transnational history encourage fresh historical practices or does it replicate older approaches? And what is the audience for national and transnational histories? Popular? Scholarly? Pedagogical? In other words, this collection explores how transnational histories interact with the nation and with historical practice itself.

\footnotetext{
${ }^{1}$ Lake and Curthoys, eds, 2005.

2 "Entangled Histories: AHA Conference 2017," https://www.theaha.org.au/call-forpapers-entangled-histories-aha-annual-conference-2017-3-7-july-2017/, accessed 5 March 2017.

${ }^{3}$ Curthoys, 2002; Crozier De-Rosa and Lowe, 2013; Lake, 2013.

${ }^{4}$ Wolfe, 2016; Banivanua Mar, 2015; Lake, 2013.

${ }^{5}$ Banivanua Mar, 2015; Morgan, 2013; Loy-Wilson, 2017; Carey and Lydon, eds, 2014; Fox, 2012; Strange, 2010.

${ }^{6}$ Guterl, 2013.

${ }^{7}$ Lake and Curthoys, eds, 2005, p.5.

${ }^{8}$ Putnam, 2016.

${ }^{9}$ See, for example, Karskens, 2009; Griffiths, 2016.

${ }^{10}$ Guterl, 2013.

${ }^{11}$ Bongiorno, 2013, p.77; Pietsch, 2016, pp.157-8.

${ }^{12}$ Chakrabarty, 2000.

${ }^{13}$ Vanessa Ogle in Shenk, 2015.

${ }^{14}$ Kramer, 2016, p.352.
} 
${ }^{15}$ Curthoys, 2015, p. 71.

${ }^{16}$ Gilmore, 1928.

${ }^{17}$ Twells, 2016.

${ }^{18}$ See for instance, Banivanua Mar 2016; Rees, 2016; Rhook, 2015. Tracey

${ }^{19}$ Deacon et al., eds, 2010. See also Deacon et al., eds, 2008.

${ }^{20}$ Colley, 2007.

${ }^{21}$ Paisley, 2012.

${ }^{22}$ McGrath, 2015.

${ }^{23}$ Piccini, 2016, esp. ch 3; Matthews, 2005.

${ }^{24}$ Banivanua Mar and Edmonds, 2010.

${ }^{25}$ Tyrrell, 1991.

\section{REFERENCES:}

Banivanua Mar, Tracey and Penny Edmonds. "Introduction." In Making Settler Colonial Space, edited by Tracey Banivanua Mar and Penny Edmonds, pp.1-24. Basingstoke: Palgrave Macmillan, 2010.

Banivanua Mar, Tracey. "Shadowing Imperial Networks: Indigenous Networks and Australia's Pacific Past." Australian Historical Studies 46, no. 3 (2015): 340-55.

Banivanua Mar, Tracey. Decolonization and the Pacific: Indigenous Globalisation and the Ends of Empire. Cambridge: Cambridge University Press, 2016.

Bongiorno, Frank. "Australia, Nationalism and Transnationalism." History Australia 10, no. 3 (2013): 77-84.

Carey, Jane and Jane Lydon, eds., Indigenous Networks: Mobility, Connections and Exchange. New York: Routledge, 2014.

Chakrabarty, Dipesh. Provincializing Europe: Postcolonial Thought and Historical Difference. Princeton and Oxford: Princeton University Press, 2000.

Colley, Linda. The Ordeal of Elizabeth Marsh: A Woman in World History. New York: Pantheon Books, 2007.

Crozier-De Rosa, Sharon and David Lowe, "Introduction: Nationalism and Transnationalism in Australian Historical Writing," History Australia 10, no. 3 (2013): 7-11.

Curthoys, Ann. “Australian History Beyond Australia," History Australia 12, no. 1 (2015): 69-74.

Curthoys, Ann. "Does Australian History Have a Future?" Australian Historical Studies 33, no. 118 (2002): 140-52;

Deacon, Desley, Angela Woollacott, and Penny Russell, eds. Transnational Ties: Australian Lives in the World. Canberra: ANU E-Press, 2008.

Deacon, Desley, Penny Russell, and Angela Woollacott, eds. Transnational Lives: Biographies of Global Modernity, 1700-present. Basingstoke: Palgrave Macmillan, 2010.

Fox, Karen. "Globalising Indigeneity? Writing Indigenous Histories in a Transnational World," History Compass 10, no. 6 (2012): 423-39;

Gilmore, Mary. "Dorothy Cottrell and Her Books." Sydney Mail, November 7, 1928, p.17.

Griffiths, Tom. The Art of Time Travel: Historians and Their Craft. Melbourne: Black Inc., 2016. 
Guterl, Matthew Pratt. "Comment: The Futures of Transnational History." American Historical Review 118, no. 1 (2013): 130-39.

Karskens, Grace. The Colony: A History of Early Sydney. Crows Nest, NSW: Allen \& Unwin, 2009.

Kramer, Paul A. "Embedding Capital: Political-Economic History, the United States, and the World." Journal of the Gilded Age and Progressive Era 15 (2016): 331-62.

Lake, Marilyn and Ann Curthoys, eds. Connected Worlds: History in Transnational Perspective. Canberra: ANU E-Press, 2005.

Lake, Marilyn. "Histories Across Borders." In Australian History Now, edited by Anna Clark and Paul Ashton, pp. 269-287. Sydney: NewSouth, 2013.

Lake, Marilyn. "Researching Australian History in the New York Public Library: Reflections on Transnational History in Practice," Melbourne Historical Journal 41 (2013): 4.

Lake, Marilyn. "White Men's Wages: The Australian/American Campaign for a Legislated Living Wage." In Outside In: The Transnational Circuity of US History, edited by Andrew Preston and Doug Rossinow, pp.74-95. New York: Oxford University Press, 2017.

Loy-Wilson, Sophie. Australians in Shanghai: Race, Rights and Nation in Treaty Port China. London: Routledge, 2017.

Matthews, Jill. Dance Hall \& Picture Palace: Sydney's Romance with Modernity. Strawberry Hills, NSW: Currency Press, 2005.

McGrath, Ann. Illicit Love: Interracial Sex and Marriage in the United States and Australia. Lincoln and London: University of Nebraska Press, 2015.

Morgan, Ruth A. "Western Australia in the Indian Ocean World - A Land Looking West?" Studies in Western Australian History 28 (2013): 1-11.

Paisley, Fiona. The Lone Protestor: A. M. Fernando in Australia and Europe. Canberra: Aboriginal Studies Press, 2012.

Piccini, Jon. Transnational Protest, Australia and the 1960s. London: Palgrave, 2016.

Pietsch, Tamson. "What was Britain? Where was its history?" History Australia 13, no. 1 (2016): 157-8.

Putnam, Lara. "The Transnational and the Text-Searchable: Digitized Sources and the Shadows They Cast." American Historical Review 121, no. 6 (2016): 377 402.

Rees, Anne. "'Bursting with New Ideas': Australian Women Professionals and American Study Tours, 1930-1960." History Australia 13, no. 3 (2016): 382-98.

Rhook, Nadia. "Turban Clad British Subjects: Tracking the Circuits of Mobility, Visibility and Sexuality in Nation-Making." Transfers 5, no. 3 (2015): 104-22.

Shenk, Timothy. "Booked: A Global History of Time." Dissent Magazine, December 17, 2015. Accessed January 10, 2017. https://www.dissentmagazine.org/blog/booked-a-global-history-of-timevanessa-ogle.

Strange, Carolyn. "Transgressive Transnationalism: Griffith Taylor and Global Thinking," Australian Historical Studies 41, no. 4 (2010): 40

Twells, Alison. "Women at the Intersection of the Local and the Global in Schools and Community History in Britain since the 1980s." In Women in Transnational History: Connecting the Local and the Global, edited by 
Claire Midgley, Alison Twells and Julie Carlier, pp.210-32. London and New York: Routledge, 2016.

Tyrrell, Ian. "American Exceptionalism in an Age of International History.” The American History Review 96, no. 4 (1991): 1031-55.

Wolfe, Patrick. Traces of History: Elementary Structures of Race. London and New York: Verso, 2016. 